\title{
Stress: should animals be fed to their potential requirements?
}

\author{
N.S. Ferguson and G.A. Lavers \\ School of Agricultural Sciences and Agribusiness, University of Natal, P Bag X01, Scottsville, 3209, South Africa \\ ferguson@nu.ac.za
}

\section{Introduction}

Due to recent and rapid improvements in the potential for lean tissue deposition, the influence of dietary amino acid balance on feed intake, growth performance and carcass characteristics is now a major concern in pig feeding (Whittemore, 1998). In addition, environmental conditions (high temperatures, high stocking density etc.) may also limit the animal from expressing its genetic potential for growth (Patherick et al., 1989; Ferguson \& Gous, 1997). Is it not plausible that under certain conditions growing pigs will not be able to express their potential and therefore should not be fed according to requirement? The answer to this question has significant implications for the production of intensively reared animals. It may be more economical to feed lower levels of nutrients under stressful conditions because the animal will not be able to meet its requirement. To investigate this problem it is necessary to apply different nutrient-limiting treatments to animals housed under different degrees of environmentally-induced stress. The following experiment was designed with this objective in mind by comparing the responses of pigs housed at three stocking densities to four feeds limiting in lysine.

\section{Materials and Methods}

The experiment was a $4 \times 3$ factorial design with the respective factors being four lysine treatments (13.5, 11.5, 9.5 and $7.5 \mathrm{~g}$ lysine/ $/ \mathrm{kg}$ feed) and three group sizes (one, seven and $13 \mathrm{pigs} / \mathrm{pen}$ or $2.0,1.0$ and $0.5 \mathrm{~m}^{2} / \mathrm{pig}$, respectively). Two hundred and sixty four female Large White x Landrace pigs were grown from 20 to $60 \mathrm{~kg}$ live weight in two different houses (group $v s$ individual). There were three replications per group treatment and six replicates per single-penned treatment. Three pigs per treatment were slaughtered at $60 \mathrm{~kg}$ for analysis of carcass composition. A summit-dilution technique was used to produce the four dietary treatments. The summit diet contained 14.0 MJ DE/ $/ \mathrm{kg}$ feed, and $13.0 \mathrm{~g}$ lysine $/ \mathrm{kg}$ (110\% of requirements) with the remaining essential amino acids at $130 \%$ of requirement, thereby ensuring that this was the limiting amino acid in the feed. A non-protein dilution diet containing the same concentrations of energy and all nutrients, other than the amino acids, was used to dilute the food of the three other feeds in the dilution series. Feeds were blended in the following proportions (summit:dilution): 100:0, 85:15, 70:30, 55:45, to obtain the four dietary treatments. A single self-feeding feed bin was placed in each pen. Residual maximum likelihood (REML) analysis in Genstat 5 Release 4.1 (1997) was used to test for significant interactions between the main effects in a linear model with both fixed (stocking density and lysine content) and random (house) effects. Linear regression analyses were conducted on all data to compare the growth responses to dietary lysine and number of pigs per pen. Starting weight was a significant covariate and therefore all analyses were adjusted accordingly.

\section{Results and Discussion}

There were no significant interactions between the main effects of lysine and pigs per pen on any production and carcass characteristic. A summary of the main effects on food intake (FI, average daily growth rate (ADG) and conversion of food into body tissue (FCR) over three different live weight periods is shown in Table 1. Similarly, Table 2 gives results for carcass composition at $60 \mathrm{~kg}$ live weight and protein and lipid retention rates (PR and LR, respectively) between 20 and $60 \mathrm{~kg}$. Over the live weight period 20 to $40 \mathrm{~kg}$ there was a positive response in FI, ADG and FCR to increasing levels of dietary lysine content. This was expected as younger pigs have a higher daily requirement for amino acids than older or heavier pigs. Although the response in FI to decreasing lysine levels was not significant from 4- $60 \mathrm{~kg}$, over the whole test period there was a significant $(\mathrm{P}<$ 0.05 ) increase in FI with decreasing dietary lysine concentrations. However this did not coincide with an increase in ADG nor an improvement in feed conversion over the $20-60 \mathrm{~kg}$ live weight range. This lack of response to lysine suggests that the lysine levels were too high over the 40-60kg live weight range and that a lower concentration in the summit diet would have been more appropriate at the heavier weights. However positive responses to increasing dietary lysine content were obtained in the carcass composition data over the 20-60 kg weight range.

This was due mainly to the higher fat and lower protein concentration and growth rates on the lowest lysine treatment. Animals grown alone ate significantly $(\mathrm{P}<0.001)$ more food than those in groups and also grew faster, 


\section{Short paper and poster abstracts: $38^{\text {th }}$ Congress of the South African Society of Animal Science}

irrespective of the live weight range. However, significantly $(\mathrm{P}<0.05)$ more food was required per $\mathrm{kg}$ gain of body weight in individually kept animals than in groups, except between 20 and $40 \mathrm{~kg}$ where there were no differences. Individually housed individuals also deposited significantly $(\mathrm{P}<0.001)$ more protein per day than both lightly and heavily-stocked pens which resulted in significantly more $(\mathrm{P}<0.05)$ carcass protein at $60 \mathrm{~kg}$ than heavily-stocked pigs but similar to lightly stocked pigs.

Table 1 The main effects of dietary lysine content and the number of pigs per pen on food intake (FI), average daily growth rate (ADG) and feed conversion (FCR) over three different live weight periods. The responses are presented as treatment means as well as regression coefficients $\left(b_{1}\right.$ and $\left.b_{2}\right)$ and their standard errors (s.e.).

\begin{tabular}{|c|c|c|c|c|c|c|c|c|c|c|}
\hline \multicolumn{2}{|c|}{ Treatment } & \multicolumn{3}{|c|}{ FI $(\mathrm{kg} / \mathrm{d})$} & \multicolumn{3}{|c|}{ ADG $(\mathrm{kg} / \mathrm{d})$} & \multicolumn{3}{|c|}{ FCR (kg feed/kg gain) } \\
\hline Lysine & $(\mathrm{g} / \mathrm{kg})$ & $20-40 \mathrm{~kg}$ & $40-60 \mathrm{~kg}$ & $20-60 \mathrm{~kg}$ & $20-40 \mathrm{~kg}$ & $40-60 \mathrm{~kg}$ & $20-60 \mathrm{~kg}$ & $20-40 \mathrm{~kg}$ & $\begin{array}{c}40- \\
60 \mathrm{~kg}\end{array}$ & $20-60 \mathrm{~kg}$ \\
\hline L1 & 13.5 & 1.64 & 2.03 & 1.87 & 0.84 & 0.91 & 0.87 & 1.95 & 2.25 & 2.16 \\
\hline L2 & 11.5 & 1.71 & 2.20 & 1.97 & 0.81 & 0.94 & 0.86 & 2.15 & 2.33 & 2.28 \\
\hline L3 & 9.5 & 1.68 & 2.16 & 1.96 & 0.79 & 0.96 & 0.89 & 2.15 & 2.40 & 2.12 \\
\hline L4 & 7.5 & 1.84 & 2.20 & 2.07 & 0.75 & 0.99 & 0.89 & 2.47 & 2.20 & 2.32 \\
\hline$b_{1}$ & & -0.030 & -0.026 & -0.030 & 0.014 & -0.013 & -0.005 & -0.078 & 0.006 & -0.020 \\
\hline s.e & & 0.010 & 0.023 & 0.014 & 0.006 & 0.006 & -0.014 & 0.014 & 0.019 & 0.013 \\
\hline $\mathrm{P}$ & & $* *$ & NS & $*$ & $*$ & $*$ & NS & $* * *$ & NS & NS \\
\hline \multicolumn{11}{|c|}{ Pigs/pen $\left(\mathrm{m}^{2} /\right.$ pig } \\
\hline 1 & 2.0 & 1.81 & 2.45 & 2.17 & 0.83 & 1.05 & 0.94 & 2.21 & 2.35 & 2.31 \\
\hline 7 & 1.0 & 1.64 & 1.95 & 1.82 & 0.77 & 0.89 & 0.83 & 2.15 & 2.19 & 2.18 \\
\hline 13 & 0.5 & 1.61 & 1.73 & 1.71 & 0.76 & 0.82 & 0.78 & 2.15 & 2.13 & 2.17 \\
\hline $\mathrm{b}_{2}$ & & -0.017 & -0.061 & -0.041 & -0.006 & -0.020 & -0.014 & -0.005 & -0.0174 & -0.012 \\
\hline s.e & & 0.004 & 0.011 & 0.007 & 0.003 & 0.003 & 0.002 & 0.006 & 0.009 & 0.006 \\
\hline $\mathrm{P}$ & & $* * *$ & $* * *$ & $* * *$ & $*$ & $* * *$ & $* * *$ & NS & $*$ & $*$ \\
\hline
\end{tabular}

Table 2The main effects of dietary lysine content and the number of pigs per pen on protein and lipid content $(\mathrm{g} / \mathrm{kg}$ ) of the empty body at $60 \mathrm{~kg}$, and protein (PR) and lipid (LR) growth rates from 20 to $60 \mathrm{~kg}$. The responses are presented as treatment means as well as regression coefficients $\left(b_{1}\right.$ and $\left.b_{2}\right)$ and their standard errors (s.e.).

\begin{tabular}{|c|c|c|c|c|c|}
\hline Lysine & $(\mathrm{g} / \mathrm{kg})$ & Protein $(\mathrm{g} / \mathrm{kg})$ & Lipid $(g / k g)$ & PR (g/d) & $\mathrm{LR}(\mathrm{g} / \mathrm{d})$ \\
\hline L1 & 13.5 & 181.2 & 132.0 & 157 & 119 \\
\hline L2 & 11.5 & 178.9 & 137.2 & 153 & 126 \\
\hline L3 & 9.5 & 176.8 & 142.2 & 159 & 140 \\
\hline L4 & 7.5 & 168.9 & 166.6 & 140 & 171 \\
\hline$b_{1}$ & & 1.94 & -5.43 & 2.32 & -8.44 \\
\hline s.e & & 0.43 & 1.50 & 1.01 & 2.35 \\
\hline $\mathrm{P}$ & & $* * *$ & $* * *$ & $*$ & $* * *$ \\
\hline \multicolumn{6}{|c|}{$\underline{\text { Pigs/pen }\left(\mathrm{m}^{2} / \mathrm{pig}\right)}$} \\
\hline 1 & 2.0 & 178.7 & 145.8 & 166 & 153 \\
\hline 7 & 1.0 & 177.3 & 136.6 & 153 & 126 \\
\hline 13 & 0.5 & 173.4 & 151.1 & 138 & 138 \\
\hline $\mathrm{b}_{2}$ & & -0.44 & 0.45 & -2.36 & -1.25 \\
\hline s.e & & 0.19 & 0.69 & 0.46 & 1.07 \\
\hline $\mathrm{P}$ & & $*$ & NS & $* * *$ & NS \\
\hline
\end{tabular}


The lack of any significant interactions between dietary lysine content and number of pigs per pen supports the hypothesis that growth responses to the first limiting nutrient in the diet are independent of the effect of higher stocking density, or more generally, independent of the level of stress. Similarly, the reduced effect of increasing the number of pigs per pen was not diminished by increasing the concentration of the most limiting nutrient. However, had the lysine content of the feeds been lower there may well have been a significant interaction. As the diets contained higher lysine levels than required, the grouped-penned animals were able to consume sufficient quantities of lysine and therefore performance was not significantly affected.

\section{Conclusion}

Although not conclusive the results in this experiment suggest that feeding according to the requirement of the animal will still give the best biological performances and carcass composition, irrespective of the number of pigs per pen.

\section{References}

Ferguson, N.S. \& Gous, R.M., 1997. The influence of heat production on voluntary food intake in growing pigs given protein-deficient diets. Anim.Sci. 64,365-378.

Genstat, 1997. Genstat 5 Release 4.1 Reference Manual 3rd Ed.Clarendon Press, Oxford.

Patherick, J.C., Beatties, A. W. \& Bodero, D.A.V., 1989. The effect of groupsize on the performance of growing pigs. Anim. Prod. 49, 497-503.

Whittemore,C.T., 1998. The Science and Practice of Pig Production. 2nd Ed.Blackwell Science, Oxford. 